\author{
Eugeniusz KOŚMICKI, PhD, Professor of the Poznan University of Life Sciences \\ Faculty of Economics and Social Sciences, Poznan University of Life Sciences \\ e-mail: eugeniusz.kosmicki@up.poznan.pl \\ ORCID: 0000-0002-6658-1157
}

DOI: $10.15290 /$ oes.2018.04.94.9

\title{
IN SEARCH OF THE PRINCIPLE OF SUSTAINABLE DEVELOPMENT - AN ATTEMPT TO EVALUATE THE CONCEPTS OF HANS CHRISTOPH BINSWANGER AND IRENÄUS EIBL-EIBESFELDT
}

\begin{abstract}
Summary
Hans Christoph Binswanger was one of the most prominent Swiss and European economists. He made attempts to diagnose the contemporary socio-economic and ecological situation in highly developed countries. He proposed 'the idea of moderation' in economic and social activities. The modern economy is based on coercion and pressure on economic growth. More and more speculative bubbles are created and their 'bursting' leads to financial and economic crises. H.Ch. Binswanger pointed to the possibility of overcoming crises and entering the path of a sustainable economy: one which does not shy away from altering the mode of its functioning.

Irenäus Eibl-Eibesfeldt was a prominent contemporary Austrian biologist, interested in studying the behaviour of humans and animals. In addition to his numerous biological studies, I. Eibl-Eibesfeldt was also the author of socio-philosophical research concerning the basic problems of economics, economy, environmental protection, and sustainable development. The role of man in nature and society is changing rapidly. An important problem of modern society is the time perspective in the processes of biological evolution and the functioning of human society. Biology also emphasises the phylogenetic basis of social actions. The current economic and political situation does not live up to the ideas of economic liberalism. The most negative effects of short-term thinking can be seen, for instance, in agriculture, industry and migration policies. It has become necessary to abandon short-term thinking and devise a long-term development strategy, a survival ethos for future generations. Both H.Ch. Binswanger and I. Eibl-Eibesfeldt contributed to the development of the concept of sustainability and to identifying its problems.
\end{abstract}

Key words: sustainable development, economics of moderation, economic growth and its consequences, financial and speculative crises, phylogenetic basis of evolution, biological and cultural evolution, perspective of short-term thinking, basic environmental and social hazards

JEL classification: Q50, Q56 


\section{Introduction}

Nowadays, stable and sustainable development constitutes a major challenge for economies and economic sciences. In practice, the term means perceiving economic processes as an element of natural processes and social development [Poskrobko, 2013, p. 21]. What is more, according to B. Poskrobko the paradigm of sustainable development makes it possible to create a new theoretical model of optimising management in the macrosystem 'environment - society - economy', and the instruments for controlling this macrosystem [Poskrobko, 2013, p. 24]. The activities in this area were initiated, among others, by two eminent German-speaking scientists: Professor Hans Christoph Binswanger, a Swiss economist and- Professor Irenäus Eibl-Eibesfeldt, an Austrian biologist and the creator of human ethology. The latter pointed at ecological and socio-economic threats. Their scientific activity, among other things, focused on the peculiarities of human evolution and resulted in the development of the concept of homo sustinens.

\section{Concept of moderation as the search for the essence of sustanable development}

H.Ch. Binswanger (born in Zurich in 1929) was one of the most outstanding contemporary economists. He considered economics to be part of socio-cultural existence. In the years 1969-1995, Binswanger was a professor of economics at St. Gallen University in Switzerland. He also held prestigious positions at the University as the director of Forschungsgemeinschaft für Nationalökonomie in the years 1967-1992, whereas in the years 1992-1995, he was the director of the Institute for Economy and the Environment (IWÖ) - the first scientific institute in German-speaking countries where economic and ecological issues were analysed jointly. In his prolific scientific career, Professor Binswanger investigated such issues as: economics related to the environment and natural resources, the theory of money, European integration, and the history of economic thought.

H.Ch. Binswanger was critical towards the fact that the foundations of the contemporary economy were based on the assumption of ceaseless technical advancement and unlimited economic growth. Thus, according to Binswanger we are trapped in the dynamics of growth of a Faustian economy, which is associated with the general self-understanding of the contemporary economy and society. Binswanger's thought focused on the following understanding of economics as a science [Kley, 2010, p. 84]: (1) subject of economics; (2) acknowledgment of unscientific forms of economic knowledge; (3) diversification of man's image; (4) philosophical and ethical character of the problems indicated by economists; (5) practical and political orientation of the discipline. H.Ch. Binswanger wanted to deepen the understanding of the subject of economics since he believed that it should not confine itself to economy alone. Economic research must take into consideration: the state, law, society, culture, and the natural environment. This is 
due to the fact that the economy is an increasingly important part of the entire modern culture and people's lives. Hence, it needs to be taken into account in its historical, institutional, and cultural context. This approach to economics was also used by the historical school of economics, popular in German-speaking societies. For H.Ch. Binswanger, economic knowledge could not come solely from economics because there are also unscientific forms of economic knowledge. In his opinion, they encompass: myths, philosophy, literature, poetry, and ethnographic knowledge. This kind of economic knowledge is also visible in works of fiction, as Binswanger proved using the example of Goethe's Faust. 'The business world' requires critical observation and expression of doubts about its functioning. Using diversified sources of knowledge, Binswanger represented a broader and more diversified image of man. Neoclassical theory presents 'the image of a man' who only strives to maximise his usefulness. Therefore, homo oeconomicus - irrespective of numerous human aspirations - constitutes a purely theoretical construct.

In their writings, economists usually refer to problems of philosophical and ethical nature. Although the instrumental approach to economics is a predominant one, it is impossible to avoid normative questions. Economic policy ought to take into consideration also such characteristics of economic activity as: stable prices, full employment, balance of payments, environmental stabilisation, and the quality economic growth. H.Ch. Binswanger supported the ethical approach to economics and was a co-author of the so-called 'economist's oath', according to which, economists' knowledge, skills and potential impact should contribute to increasing the prosperity of the state and the world; whereas prosperity ought to enable everyone to live in dignity and economic freedom, while natural resources and production capital should be used in such way that enables the future generations to find the world worth living in when they grow up [Kley, 2010, p. 90]. According to Binswanger, economics is chiefly a practically oriented discipline, whereas the development of economic theories must not remain an end in itself. Such practically oriented economics also has a political character. H.Ch. Binswanger considered his activity 'political' and pursued it for more than forty years. In his viewpoint, political activity must be given new impulses by transmitting new ideas. Binswanger saw himself as a moderate liberal, and more broadly - as a pragmatically oriented liberal humanist.

H.G. Nutzinger, who made an attempt to assess Biswanger's scientific activity. claims that the basic problems that are characteristic for the entire activity of Hans Christoph Binswanger are included in the book Money and nature, published in 1991 [Nutzinger, 2010, p. 122]. Also another book, Money and magic, (from 1985) should be considered in the context of these views. In the latter book, the author not only offered an economic interpretation of Goethe's Faust, but also proclaimed Faust to be a prototype of 'modern man', who treats the entire world as his own 'dominion', i.e. strives to conquer the world in order to gain profits [Nutzinger, 2010, p. 122; Binswanger, 1991, 2005]. However, this point of view ultimately leads to a global socio-economic and ecological crisis. H.Ch. Binswanger associated the main problems of the economy with the stabilisation of energy consumption, reduction in 
the use of resources and devastation of the natural environment, as well as with securing the working positions. As an advocate of ecological farming policies, Binswanger expressed his negative opinion of the present development of the farming sector. He supported the plan to introduce quality growth in the conditions of natural and social limitations. The call for moderation in sustainable management is expressed in his book Towards moderation [Binswanger, 2010, 2016]. In this perspective, institutional changes in the monetary and financial sector, as well as low (but stable) global rate of growth, are supposed to be factors which will prevent economic growth from being transformed into a variety of speculative bubbles. The dark side of the growth compulsion is the temporary shrinkage of the economy and economic crises (including especially financial ones), as well as low-level stabilisation. Considerable transformations are also necessary in such sectors as farming and energy supply. Although he was a firm supporter of renewable energy, Binswanger had a critical attitude towards the use of wind energy. Moreover, he strongly rejected the possibility of using nuclear energy.

He believed that it was necessary to shift - in a rational manner - from the concept of maximum growth economics towards 'the economics of moderation'. What needs to be avoided is the spiral of money making, economic growth, and environment destruction. In his view, the protection of sustainable foundations of economic activity, e.g. energy reserves and sustainable satisfaction of needs, has become feasible nowadays. The modern economic crisis concerns three spheres: money, real economy, and the environmental foundations of social and economic life. New institutional and legal frameworks are necessary for the economy of moderation.

In the activity of H.Ch. Binswanger, major importance was attached to the history of economic thought and its development. He was well-versed in the history of economics. He conducted research into the history of introducing paper money, e.g. in the experiment of the banker J. Law in the $17^{\text {th }}$ century. According to Binswanger, another important problem was the theory of imaginary needs created by G. Schlosser, who was Goethe's brother-in-law, as well as the theory of fair wages, created by J.H. von Thünen. Additionally, Binswanger devoted much attention to the interpretation of Goethe's Faust and to the activities of the main protagonist. Three aspects of Faust appeared to be particularly essential for him: the creation of paper money, the institutionalisation of the Roman concept of ownership, and the possibility of wide use of mechanical energy in an economy. With reference to Faust, Binswanger pointed out that the development of capitalism was associated with ruthless expropriation of small holders (Philomen and Baucis), destruction of the natural environment, and the illusory belief in almost limitless possibilities of technical and civilisational achievements.

L. Ribaux briefly characterised H.Ch. Binswanger as a politician. This was owing to the fact that Binswanger was politically involved as a member of the Town Council of St. Gallen and as the author of the proposal to establish the EU Ecological Council in order to stop the dynamics of 'blind' growth and development inconsistent with ecological and social requirements. Binswanger associated the 
material world of the economy with social phenomena. His activities and their effects are characterised by ideological openness and have a human dimension [Ribaux, 2010, p. 157].

In 2006, H.Ch. Binswanger published a book entitled The Growth spiral. Money, Energy and Imagination in the Dynamics of the Market Processes [Binswanger, 2011]. It was an attempt to explore and explain the phenomenon of economic growth, typical of contemporary capitalism, or rather the continuity of growth which has adopted the character of a development spiral. The concept of economic growth gained popularity as late as in the 1960s. Characteristically, in the neo-classical theory of economics, money and nature (along with energy and other natural resources) play a very insignificant role. But only when these production factors are jointly taken into consideration it is possible to create a new approach in scientific and political debate on the conditions and possibilities of economic growth.

The problem of growth can be properly explained only provided a deep reorientation of contemporary economics, because the economy of today should be understood as a spiral of growth. The true reason for the pressure on growth is the way in which the modern economy functions: it is oriented to perpetual growth. However, this is not about maintaining a high rate of growth, but a minimum (global) rate of growth. The estimated minimum rate of growth for the global economy amounts to $1.8 \%$, assuming that a single currency area and natural differences are preserved [Binswanger, 2011, p. 295].

Explaining the spiral of growth, its premises and consequences lie at the basis of the theoretical analysis of economics, which comprises the following components [Kośmicki, 2011, pp. 11-15]:

A market is essentially different from exchange between business entities, which in fact supply themselves. A market entails interaction between companies, which specialise in production and households, which specialise in consumption. The shift of production into companies released market forces and generated a comprehensive division of labour.

In this respect, enterprises are artificial constructs which need capital in the form of advance payment for purchasing production services from households before production through the sale of products can begin. As compensation for the associated risk, enterprises expect a profit.

Money is an integral element of the modern economy. The impact of money is reinforced by the process of its creation in the bank system. Thanks to it, banks are capable of granting new credits which enable enterprises to invest and expand production.

Alongside labour, energy constitutes the most important production factor. It complements and frequently replaces human work. Energy and other natural resources are derived - on an ongoing basis - from the natural environment.

Human creativity finds increasingly diverse products that satisfy the emerging new needs. Hence it has become an important production factor, associated with labour, enabling continuous economic growth through the expansion of demand. 
The exploitation of nature as a reservoir of natural resources, a production site, or a waste disposal site, contributes to the rapid shrinkage of natural areas which could serve as living space. Unspoilt natural areas are becoming increasingly rare. However, living space, in the broad sense of the word, can be anyone's property. Therefore, it is impossible to charge for using it.

In view of the above, competition in the modern economy does not by any means lead to a general economic equilibrium or to optimal allocation of limited natural resources. Its consequence is economic growth with increasing expenditures of households on goods produced by enterprises. Aristotle's contradistinction between a stationary economy and a growth economy has preserved its cognitive significance to the present day. This contradistinction was later forgotten in the neoclassical theory, which adopted the general concept of Walrasian equilibrium [Binswanger, 2011, p. 306].

Without taking into consideration the significance of nature (and energy in particular), money and human creativity, the essence of growth remains unexplained, as evidenced by the neoclassical theory.

According to Binswanger, the objective of unlimited economic growth is a mere illusion which results in the intensification of increasingly more difficult economic and social problems. It poses a threat to both the present and future generations as regards the possibility of realising their life purposes on a more secure basis. There emerges the necessity of further systematic development of the theory of economics. Money and nature must be analysed jointly and the neoclassical theory of the environment in economics should be critically assessed. Unless this happens, speculative bubbles will continue to swell and burst, leading to further financial, economic, and ecological crises [Binswanger, 2010].

In the opinion of H.Ch. Binswanger, ecological issues cannot be understood as an economic interpretation of the differences between supply and demand for environmental services. Neither can the market mechanism be used for this purpose. The lack of market self-regulation necessitates ecological policies. The unreliability of the market results mainly from two factors: external costs and the necessity to provide public goods. Environmental protection is threatened by increasingly widespread expectations on the part of the economy: cheap and sufficient energy supply; guaranteeing ever greater mobility and constant development of communication trails; cheap and rapid waste removal; the problem of excessive risk taken by enterprises and private persons only to a specified upper limit. Owing to this, societies develop economic strategies oriented at large profits. The expectations of the economy are utterly inconsistent with environmental preservation and the rights of employees. Therefore, more comprehensive reforms are needed to dampen these tendencies to burden the environment and shift the economy onto a path of moderation [Binswanger, 2010, p. 201].

Binswanger pointed to the possibilities of emerging from the present crisis and entering the path leading to a moderate (sustainable) economy. These possibilities include the following [Binswanger, 2010]: (1) new structuring of the monetary system; (2) activities oriented at the stability of the principles governing the 
functioning of companies; (3) long-term nutrition security; (4) sustainable economy of resources; (5) ownership obliges - patrimonium versus dominium; (6) community services as a supplementation paid services; (7) the principle of subsidiarity in environmental protection; (8) EU Ecological Council as the representative of activities for the future generations.

Constant economic growth after WW II has led to immense multiplication of wealth. However, more and more frequently it causes speculative financial bubbles which also affect the real economy and manifest themselves in the form of economic crises. Efficient control of money creation involves relevant reforms of the monetary system, i.e. the idea of 100\% reserve banking (already proposed by Irving Fisher), in accordance with which the central bank would have the exclusive right to issue money, while other banks would be obliged to have their liabilities covered in $100 \%$ by the central bank. Banks could grant credit only up to the amount of money possessed by the central bank. This would exclude inflation and deflation, speculative demand for money, and would result in economic growth within the limits of the sustainable use of natural resources. The $100 \%$ money perspective would cause: a reduction in growth compulsion, the modification of growth by means of avoiding losses connected with it, or at least their substantial reduction, and the development of additional activities for more sustainable economic development. The reform of the monetary system would be the starting point for the strategy of moderation and stability.

The dynamics of the modern economy is, to a large degree, determined by public limited-liability companies - deriving profits from their business activity or revenues from interest rates. Shareholders are used to expecting increasing profits and growing value of stock market shares. Therefore, they are interested in the constant growth of companies. In the twentieth century, public limited-liability companies gradually began to dominate the economy. This caused oligopolisation and monopolisation of markets, associated with the increase in profits achieved by companies at the expense of consumers. Not only did public limited-liability companies contribute to a reduction in competition, but they also encouraged the tendency to undertake speculative activities, i.e. to create financial bubbles. Such activities were partly responsible for various economic crises in the past (e.g. in 1929), as well as for the 2008-2010 crisis. Speculative purchases of shares are extremely dangerous and they are successful only when bank interest rates remain low. Hence the necessity to transform public limited-liability companies into alternative forms of enterprises. If this happened, new management methods would be possible: the maintenance of competition, greater stability of the economy, orientation of the economy towards the requirements of environmental protection and the rights of employees. The reform of public limited-liability companies could aim to return to the limitations which applied in the nineteenth century. Civil companies and foundation companies are far more oriented at sustainability.

It has become necessary to guarantee nutrition security to consumers. Presently, farming policies are usually based on making transfer payments. They are indispensable because farming cannot be based solely on maximising profits, but should 
follow the principles of sustainable development, i.e. the maintenance of the potential to make a profit in the long time perspective. They refer to both market conditions and production conditions, while farming products are exchanged in the market, where price competition prevails (the result are low profit margins). What is also characteristic is the inflexibility of demand. In farming, the soil is both the location and the basic means of production, whereas in industry, it is only the former. The agricultural sectors of countries relying on export, or of highly developed countries, are particularly vulnerable. Owing to this, considerable food supply shortages are, in a sense, inherent in the system. What is at stake is not only nutrition stocks, but also the preservation of the cultural landscape or repopulation of rural areas. Therefore, farming is in dire need of sustainable development because the basic means of production, i.e. soil, must regenerate every year. In farming, it is impossible to strive for maximising profit in order to keep up with the industry.

Stability also entails a more economical approach to renewable and nonrenewable resources. The industrial revolution led to considerable exploitation of natural resources. In the case of non-renewable resources, it is possible to introduce the principle of exponential saving in order to preserve these resources for as long as possible. What is most significant is the reduction in the use of energy which would accompany slower GDP growth, as well as various activities aimed at increasing the efficiency and frugal use of energy and raw materials.

As regards the use of natural resources, there arises a serious problem of proper ownership relations. In traditional cultures, the dominant concept of ownership was 'patrimonium', wheareas nowadays the concept of 'dominion' prevails, which has Roman origin. In the case of 'patrimonium', ownership is perceived in a generational perspective, while proper natural and social conditions are preserved. The principle of stability is crucial not only for preserving the natural environment, but also for the buildings and works inherited from ancestors.

Numerous economic activities undertaken outside paid employment bring benefits for the community. Labour markets are characterised by increasing automatisation and computerisation of business processes. Helping the local community ought to involve: social care and assistance; work for the benefit of families; assistance for senior citizens; public security; environmental protection; farming; sport; integration of foreigners; education and upbringing, work with youth; work for development.

In environmental protection, a large role is played by the principle of subsidiarity. It implies that in state structures there are various decision-making tiers and the competition potential ought to be regulated in such way that they are undertaken in a constructive manner. The principle of subsidiarity is indicated as one of the basic principles of the functioning of the European Union. Subsidiarity may denote the delegation of powers either downwards or upwards, because in the scope discussed by this paper, people who have suffered ecological loss are the starting point. It has been noted that the future generations do not have real representatives because the political and economic system is based on a short-term perspective. Possible change would require the formation of the so-called Ecological Council as 
an essential organ of the European Union. Its members would include eminent experts in environmental protection. The Ecological Council ought to be a component of the democratic system and have proper legitimacy. Apart from its role as the advocate of environmental interests and the political controlling organ, the Ecological Council would also perform a fundamental consulting function. In general, it would have autonomy, responsibility, and competences in terms of acting for the preservation of the natural foundations of human existence. According to H.Ch. Binswanger, the Ecological Council must be equipped with appropriate infrastructure that will enable it to perform its own tasks, whereas in the political system it will serve as a signpost of sustainable development [Binswanger, 1994, 2010, p. 201; Kośmicki, 1995a, pp. 195-201]. Unfortunately, so far such a Council has not been established - most probably owing to the dominance of short-term economic interests.

\section{Contemporary social and ecological hazards according to Irenäus Eibl-Eibesfeldt}

Professor I. Eibl-Eibesfeldt was one of the most distinguished contemporary biologists who studied human and animal behaviour. His best known works include textbooks on the behaviour of animals and humans [Eibl-Eibesfeldt, 1987, 1995]. Apart from numerous publications devoted to strictly biological problems, EiblEibesfeldt was also the author of interesting books on philosophical and social subjects, concerned, among other things, with the basic problems of sustainable development, economy, and environmental protection. In his works, Eibl-Eibesfeldt did not avoid difficult social and ecological problems connected with rapid changes in human behaviour resulting from the development of the economy, culture, or altered position of man in nature and society [Eibl-Eibesfeldt, 1994, 1998, 1998a, 2000]. The fundamental problems of contemporary society are the subject of the book In the trap of short-term thinking, where the author analyses the time perspective in the processes of biological evolution and the functioning of human society [EiblEibesfeldt, 2000a]. He sought a more in-depth explanation of the present situation of man in the evolution of human kind, i.e. in the processes of phylogenesis. People frequently behave as if they still belonged to the hunting tribes of the glacial period, when ruthless competition determined the survival of a group. However, competitive behaviour in the modern economy, politics and society poses a direct hazard to the natural bases of existence [Eibl-Eibesfeldt, 2000]. The author points at the following phylogenetic adaptations of the behaviour of animals and people: motor patterns; perception (innate recognition) patterns; desired patterns; mechanisms motivating dispositions in learning principles; experiments in the form of cultures. In order to survive, man needs the ethos of survival that would use such positive human features as: concern for offspring, responsibility for family, or pursuit of preserving nature. 
According to I. Eibl-Eibesfeldt, social behaviour of man is, to a larger degree determined by phylogenetic adaptations than by his behaviour towards other species. The basic characteristics of human behaviour developed already in the Paleolithic period, when our ancestors lived as hunters and gatherers in small communities. The hunting and gathering period accounts for as much as $98 \%$ of the history of humankind. Our phylogenetic heritage is expressed to the fullest in such emotions as: love, hatred, fear, and jealousy. Phylogenetic determinants govern such human needs as: demarcation of groups, inclination towards territorialism, pursuit of social dominance. Furthermore, cultural development has been modifying the social and ecological conditions of human existence.

Ethology, a biological science devoted to studying behaviour, has developed relatively recently. Its beginnings date back to the 1930s. Human ethology was ultimately distinguished from the other social sciences as late as in the 1960s. Despite a relatively short history, it is possible to identify the following stages in the development of biological research on behaviour: classical ethology, genetic ethology, and sociobiology [Kośmicki, 1988]. By means of its theories regarding kin selection and the concept of inclusive fitness (general adaptive value), sociobiology explains in evolutionary categories the reasons for the development of social behaviours, including altruistic ones, of animals and people. At present, the problem of classical ethology, genetic ethology, and sociobiology comprises the entirety of biological research on behaviour. Contemporary ethology and sociobiology treat the behaviours of animals as the most flexible organ and an important factor which has an impact on evolution. In the case of man, the greatest importance is attached to the development of culture, whereas the co-evolution of genes and culture is a distinctive peculiarity of humankind. Contrary to most animals, man is capable of comprehensive adaptation to the natural conditions. In biological terms, man is not a specialist, but a generalist. However, we also need culture to survive.

The phylogenesis of man took place in another time dimension than the contemporary economic activity. And yet, some economists still regard the selection that occurs in nature as the model for economic activity, assuming, however, too short time periods and forgetting about the long-lasting effects of such a risky strategy. Human activity cannot be derived directly from nature. What counts in nature is the survival of one's own offspring, i.e. the survival of genes [Wickler, Seibt, 1977].

Traditional ethological research focused on the physiological and descriptive aspects of behaviour, most frequently from the perspective of the development of individuals or shorter periods of behavioural development. Meanwhile sociobiologists claim that this fails to explain why certain features occur in a population and why they are preferred by natural selection. Particular problems of behaviour can be considered both in terms of proximate and ultimate causation. Sociobiologists believe that in order to obtain a satisfactory explanation of a behaviour we must take into account both its proximate and ultimate causes.

The emergence of larger communities resulted in the development of constant leadership, state apparatuses, and legal systems. In large societies, a significant part is 
played by identification with symbols and susceptibility to indoctrination. The formation of large groups occurred as a result of referring to family assemblies, where a mutual ancestor was frequently of primary importance. The distinction between 'them' and 'us' still remains essential in large anonymous societies, while the motive of the 'enemy' is sometimes exploited by political and religious leaders.

The creation of large anonymous communities results from such social predispositions as group bonds, mutuality, and obedience. Social groups are also united around certain symbols and bound together by people's susceptibility to indoctrination using culturally developed patterns. Emotional bonds with the symbols of societies are a result of learning. The fanaticism of religious wars and political ideologies stem from instilled convictions (most frequently during childhood) and methodical indoctrination.

The rapid development of human civilisation within the last 15,000 years has led to a critical situation in terms of the functioning of phylogenetic behaviour patterns. In the changed cultural conditions, the orientation towards competition and pursuit of power seem to be particularly dangerous. What is characteristic of man is the opportunist attitude towards the environment in order to fully exploit the available resources, irrespective of future consequences. From this point of view, competitive success is rewarded with a surge of hormones, whereas the joy resulting from the success generates further unreflective behaviours. Therefore, in our times, those archaic short-term competitive strategies are a threat to the basic resources and the existence of the future generations.

Such political ideologies as Marxism or liberalism originally had noble assumptions. The former led to the establishment of bloody dictatorships and rationing of food, instead of putting an end to the control of one man over another, or eliminating exploitation. On the other hand, liberalism, which is based on the rule of law, freedom of an individual, and opposes concentration of state authority, has resulted in the creation of a global market economy, dominated by transnational consortia governed by people striving for instant success at all costs. The consequences of such a short-sighted way of thinking are especially noticeable in farming, industry, and migration policy.

Over the centuries, farming has developed various rules regarding the preservation of basic ecological conditions for the future generations. However, within the last thirty years, the situation has changed substantially. Nowadays, traditional farming (based on farmer's work) is being replaced by industrial monoculture farming and large-scale livestock production, which poses an immense danger to soil and soil organisms. Worse still, extensive livestock farming directly leads to proliferation of viral pathogens and rapid dissemination of many dangerous diseases. The BSE epidemic can serve as a warning against this approach to food production. Eibl-Eibesfeldt noticed that mass breeding of animals is irresponsible - from the social, economic, and health perspective [Eibl-Eibesfeldt, 2000a; Meyer 1981; Meyer, 2010, p. 75]. Modern European countries and the European Union are running a considerable risk and bear responsibility for the future effects of this 
model of farming, which at the moment benefits mainly major agricultural entrepreneurs.

As a result of the immense development of new technologies of the information era, financial markets have become internationalised and barriers to international trade have been significantly reduced. This has resulted in the development of the global market of production and services. This phenomenon, referred to as globalisation, has a huge impact on the modern economy and society. However, there occur such disturbing phenomena as: threats to democratic values, progressive impoverishment of vast groups of population, endangering the foundations of the functioning of social market economy. According to Eibl-Eibesfeldt, the European Union should take measures to counteract the negative effects of globalisation, and at the same time take advantage of the achievements. So far, no appropriate international institutional solutions or mutual economic, social and ecological norms in this aspect have been established.

The populations of the industrialised countries of Europe, USA, Canada, and Japan live in moderate prosperity, which results mainly from the use of fossil energy carriers. However, e.g. the resources of crude oil will suffice only for approx. 150 years [Eibl-Eibesfeldt, 2000a, p. 129]. In the increasingly overpopulated world, poverty is becoming an ever more serious problem, which prompts many people to migrate to the countries of Western Europe and the USA. Simultaneously, according to Eibl-Eibesfeldt, each solidary community represents chiefly its own interests. That is how we have been programmed over the long history of phylogenesis [EiblEibesfeldt, 2000a, p. 141]. It is worth emphasising that the differences in customs and everyday life intensify the differences between local communities and migrants.

Unless the population of Europe finds new energy carriers and raw materials, there will arise the necessity of gradual but drastic reduction in the number of inhabitants in order to maintain the achieved level of civilisation. For instance, as G. Pillet has calculated, in the conditions of energy and economic autarchy, Switzerland could have only 900,000 inhabitants (instead of the 7 million it has now). Nowadays, Switzerland derives 3.5 times more materials and energy from external ecosystems than it has on its own territory. Similar calculations for the USA - given the current use of energy and standard of living - estimate the optimal number of inhabitants of this country at a maximum of 40-100 million inhabitants. In this respect, the global ecological situation is becoming almost dramatic. The share of the world's population accounts for just $1 \%$ of its total biomass, but people (including pets) are already consuming as much as $25 \%$ of the initial global net production achieved in the process of photosynthesis. Taking into consideration only terrestrial ecosystems, people (including pets) consume as much as $40 \%$ of this global net production.

There arises a fundamental problem concerning the conditions of further existence of humankind in the third millennium. There are only two possibilities: relying on nature's self-regulation or reasonable planning of the future of mankind. The first option would be very painful since it would lead to the above-described population slump and to the creation of general socio-political mayhem. The 
symptoms of such chaotic and destructive processes are increasingly evident in some areas of the world, especially the Middle East and Africa. However, social peace and preservation of the natural environment are possible only in such an economic space where comparable level of incomes and similar ecological and social norms are preserved. Only those communities whose economic activities are purposeful and conducted with a view to the future will be capable of uniting into large-scale spheres of peace and joint economic efforts. In such areas, economic and social conditions may gradually become more equal. Therefore, in Eibl-Eibesfeldt's view, the European Union could develop into such a multi-territory space, with gradual involvement of Eastern Europe, including Russia [Eibl-Eibesfeldt, 2000, p. 160].

We are living in the times of marked concern about the future: the rates of unemployment and poverty are soaring in many places, and people's economic activity is becoming more and more intense, but tends to focus on short-term goals. In this context, it should be noted that it was in Europe where the concepts of freedom and equality of citizens, or democracy and social market economy developed. What is more, the countries of Europe ought to notice their unique opportunity to serve the global community as spiritual leaders [Eibl-Eibesfeldt, 2000, p. 169]. However, it is necessary to abandon short-term thinking and develop a long-term strategy so as to build an ethos which will ensure the survival of the future generations.

In 1988, Eibl-Eibesfeldt wrote an important work entitled Der Mensch, das riskierte Wesen: Zur Naturgeschichte menschlicher Unvernunft [Eibl-Eibesfeldt, 2000]. In the book, the founder of human ethology points at various phylogenetic adaptations in terms of perception, processing of information, ways of thinking, and human behaviour. He states that over the last few decades, research has shown that our social behaviours, as well as our way of thinking and perceiving, are to a large degree determined by phylogenetic adaptations [Eibl-Eibesfeldt, 2000, pp. 71-72]. The following fundamental questions arise here: Does humankind still have the chance to survive in the future? What prevents people from behaving in a more rational manner? According to Eibl-Eibesfeldt, the answers to these questions should be sought in our biological heritage. Originally, man was adjusted to the conditions of small communities, to the hunting and gathering lifestyle. These adjustments usually prove insufficient for the conditions of the contemporary anonymous mass society and the progressive mechanisation and computerisation of life. Contemporary people live in a world which, although created by themselves, has already become unsuitable in many aspects.

According to Eibl-Eibesfeldt, the most important threats to modern humakind include: the danger associated with fear; aspiration for power and limitation of one's freedom; excessive inclination towards 'goodness' and 'virtue'; violence and war; and the fatal dynamics of human inventions and organisations.

The fear of being dominated by others, which is at the same time fear for one's own existence, is becoming a fundamental problem. This fear makes us, as if preemptively, strive for domination over other people. This regards both the 
relations among societies and among individuals. As societies develop, the anonymous nature of interpersonal relationships increases, while aggression and fear in mutual social relationships keeps growing. Excessive fear causes an inclination to authoritarian rule and puts liberal and democratic models of government at risk. In such circumstances, people lose their individuality and independent way of thinking and submit to demagogic and populist leaders who 'guarantee', somewhat in advance, law, order, and justice.

For instance, the idea of 'tabula rasa' with reference to man and the conviction that all the differences between people result from different up-bringing have long been debunked by science, and yet they persist in society. Eibl-Eibesfeldt also regarded as scientifically false and socially harmful, various movements defying modern scientific dogma (e.g. attempts to introduce the so-called scientific creationism rejecting the theory of biological evolution).

TABLE 1.

Primeval socjety versus contemporary industrial society

\begin{tabular}{|c|c|}
\hline Primeval society & Modern industrial society \\
\hline $\begin{array}{l}\text { Individualised society. Three-generation } \\
\text { family, small groups, trust and close } \\
\text { relationships in the 'we' group. }\end{array}$ & $\begin{array}{l}\text { Anonymous large society. Lack of trust } \\
\text { determines relations with unknown members } \\
\text { of the 'we' group. Formation of communities } \\
\text { and families to a large degree weakened. } \\
\text { Burden caused by fear Manipulation of } \\
\text { symbols. }\end{array}$ \\
\hline $\begin{array}{l}\text { Leadership on pro-social basis. Leadership } \\
\text { positions justified by pro-social features and } \\
\text { specialist competences. }\end{array}$ & $\begin{array}{l}\text { Domination of leaders and interest groups. } \\
\text { Inclination to expansion of repressive } \\
\text { relationships of dominance within the } \\
\text { anonymous 'we' group. }\end{array}$ \\
\hline $\begin{array}{l}\text { Economic independence. Largely autarchic } \\
\text { family. Division of work solely between } \\
\text { marriage partners. "No bushman is } \\
\text { unemployed at any time". }\end{array}$ & $\begin{array}{l}\text { Dependence on work and profession. Sword } \\
\text { of Damocles in the form of unemployment } \\
\text { and poverty. Strong fears concerning future } \\
\text { existence. }\end{array}$ \\
\hline Closeness of nature. & Limited direct contact with nature. \\
\hline $\begin{array}{l}\text { Emotional attachment to challenges of life } \\
\text { full of risk: craving for risk and need to } \\
\text { compensate for deprivations. }\end{array}$ & $\begin{array}{l}\text { Lack of adjustment to burdens of } \\
\text { contemporary life, stress at work, lack of } \\
\text { physical challenges, craving for risk satisfied } \\
\text { by ersatz activities. Modern welfare leads to } \\
\text { its underestimation. }\end{array}$ \\
\hline
\end{tabular}

Source: [Eibl-Eibesfeldt, 1995, p. 58].

Eibl-Eibesfeldt observes that the issue of freedom and problems of authority/ power have always had key importance in society. Debates on freedom mostly focus on social freedoms. In this sense, we are free only when we can decide about our life on the basis of our own will - without being restricted by others. The dominance of 
another nation over our society is regarded as a particularly serious limitation of freedom. The problem of freedom is closely related to the issue of power in a society and the selection of appropriate leaders. The increasing inclination to conformism, social apathy, and blind obedience to false role models. are becoming dangerous factors.

Other risks are associated with an excessive propensity for 'virtue' and 'goodness'. According to Eibl-Eibesfeldt, many socially acclaimed heroes, both saints and ascetics, have been overcome by the 'madness of virtue'. The examples of such a mode of behaviour may be too much love for one's country (nationalism and chauvinism), the destruction of the culture of primeval people by the activity of some fundamentalist Christian missions in developing countries, and admission to large numbers of foreign ethnic groups to one's country.

Eibl-Eibesfeldt emphasises that many difficult problems are caused by aggression and wars. All the living organisms have a natural proclivity for aggressive behaviours, but war is a typical symptom of human 'cultural evolution'. Therefore, it is necessary to understand the role it has played so far in the relationships between human societies. The war itself does not result from any biological features formed during evolution, but is a product of typical 'cultural evolution'.

Considerable risks are also attached to the inherent dynamics of some discoveries and inventions. At some point, they seem to live lives of their own, becoming hazards to humankind. The tendency to constantly expand is noticeable in military and bureaucratic machineries. In their aspiration to cater for all the basic human needs, social institutions tend to nudge entire societies back to the 'childhood' stage of development, involving greater dependence on others. This direction of social development was already envisioned by the famous writer Aldous Huxley.

\section{Conclusions}

The implementation of the principles of stable and sustainable development constitutes a major challenge for the economy, society, and the science of economics. Economic activity should be treated both as part of natural processes and socio-cultural development. There is an ongoing debate on the essence of this conception and the possibility of its implementation in the economy and society. H.Ch. Binswanger and I. Eibl-Eibesfeldt also became involved in the work as scientists and advocates of the idea. They indicated the following problems:

1. In the opinion of H.Ch. Binswanger, we need such a sustainable economy which can be described as moderate. To achieve it, we need: new structuring of the monetary system; orientation to the stability of the principles regarding the functioning of companies; long-term nutrition security; sustainable resource economy; ownership understood as patrimonium; the principle of subsidiarity in environmental protection; EU Ecological Council as an institution speaking on behalf of future generations. 
2. Binswanger observes that it is becoming crucial that we develop a new approach to economics, comprising: the character of the subject of economics, consideration to non-scientific forms of economic knowledge; modification of the present image of man - withdrawal from the concept of homo oeconomicus; philosophical and ethical character of the problems formulated by economists; practical and political orientation of economics.

3. It is necessary to depart from the concept of constant economic growth and turn towards an economy of moderation. The present economic growth is adopting the form of a growth spiral, leading to various ecological and social hazards.

4. According to Eibl-Eibesfeldt, social behaviours of man are still determined by phylogenetic adaptations dating back to the Paleolithic period, although now these behaviours occur in completely different socio-economic and technical conditions.

5. Primeval societies fundamentally differed from modern societies, which are based on increasingly rapid economic and cultural evolution.

6. Eibl-Eibesfeldt presents the most important threats to contemporary humankind: the danger associated with fear, which leads to increased competition and various forms of aggression; aspiration for authority and restriction of human freedom, among other things, by means of various forms of indoctrination; excessive inclination to 'goodness' and 'virtue'; dissemination of violence and wars; substantial dynamics of using inventions and organisational development, also contrary to real human needs.

7. Contemporary people live in an economy and society which they have themselves created, although in many respects their shape has ceased to suit both humans and the biosphere.

8. It is necessary to abandon short-term thinking and develop long-term strategies which will ensure the survival of future generations. The most negative effects of a short-term way of thinking are especially observable in farming, exploitation of natural resources, power supply, and migration policies. The doctrines of liberalism and Marxism have both led to many economic and social changes which are incompatible with the conditions of sustainable development.

In conclusion, it needs to be emphasised that the scientific work of both H.Ch. Binswanger and I. Eibl-Eibesfeldt has helped to explain the uniqueness of human evolution - its transition to cultural evolution (also in economic terms) and to the development of the concept of homo sustinens as the image of man in the conditions of sustainable development. Additionally, they provided an impulse to analysis of the types of societies with their basic mechanisms of resource exploitation; the stages and mechanisms of people's impact on nature; ecological crisis in the conditions of the existence of the so-called 'complete world', as well as the development of the ecology of time as the challenges of the contemporary era. 


\section{References}

Alland A., 1970, Evolution und menscbliches Verhalten, S. Fischer, Frankfurt am Main.

Binswanger H.Ch., 1985, Geld und Magie. Deutung und Kritik der modernen Wirtschaft anhand von Goethes Faust, Thienemann, Stuttgart.

Binswanger H.Ch., 1988, Die Glaubensgemeinschaft der Ökonomen. Essays zur Kultur der Wirtschaft, Gerling Akademie Verlag, München.

Binswanger H.Ch., 1991, Geld und Natur. Das wirtschaftliche Wachstum im Spannungsfeld zwischen Ökologie, Thienemann, Stuttgart.

Binswanger H.Ch., 2006, Die Wachstumsspirale. Geld, Energie und Imagination in der Dynamik des Marktprozesses, Metropolis Verlag, Marburg.

Binswanger H.Ch., 2010, Vorwärts zur Mässigung. Perspektiven einer nachbaltigen Wirtschaft, edition 2., Murmann, Hamburg.

Binswanger H.Ch., 2011, Spirala wærostu. Pieniadz, energia i kreatywnośc w dynamice procesów rynkowych, Zysk i S-ka, Poznań.

Binswanger H.Ch., 2016, Die Wirklichkeit als Herausforderung, Grenagänge eines Ökonomem, Murmann Publishers GmbH, Hamburg.

Binswanger H.Ch., Frisch H., Nutzinger H.G., Schefold B., Scherhorn G., Simonis U.E., Strümpel B., 1988, Arbeit ohne Umweltzerstörung. Strategien für eine neue Wirtschaftspolitik, edition 2., S. Fischer, Frankfurt am Main.

Costanza R., Cumberland J., Daly H., Goodland R., Norgaard R., 2001, Einführung in die Ökologische Ökonomik, Deutsche Ausgabe, Stuttgart.

Der Mensch Evolution, Natur und Kultur. Beiträge zu unseren heutigen Menschenbild, 2010, Oehler J. (ed.), Springer, Heidelberg-Dordrecht-London-New York.

Doob L., 1995, Sustainers and Sustainability. Attitudes and Action for Survival, University Press, London.

Eibl-Eibesfeldt I., 1955, Die Biologie des menschlichen Verbaltens. Grundriss der Humanethologie, Piper, München-Zürich.

Eibl-Eibesfeldt I., 1973, Der vorprogrammierte Mensch. Das Ererbte als bestimmender Faktor im Menschlichen Verhalten, Molden, Wien.

Eibl-Eibesfeldt I., 1987, Grundriss der vergleichenden Verbaltensforschung, edition 7., Piper, München.

Eibl-Eibesfeldt I., 1994, Wieder die Misstranensgesellschaft. Streitschrift für eine bessere Zukunft, Piper, München.

Eibl-Eibesfeldt I., 1995, Die Biologie des menschlichen Verbaltens. Grundriss der Humanethologie, edition 3., Piper Verlag, München.

Eibl-Eibesfeldt I., 1998, Krieg und Frieden aus der Sicht der Verbaltensforscbung, Piper, München.

Eibl-Eibesfeldt I., 1998a, Liebe und Hass. Zur Naturgeschichte elementarer Verhaltensweisen, edition 12., München.

Eibl-Eibesfeldt I., 2000, Der Mensch - das riskierte Wesen. Zur Naturgeschichte menschlicher Unwernunft, edition 4., Piper, München-Zürich.

Eibl-Eibesfeldt I., 2000a, In der Falle des Kurzeitdenkens, Piper, München-Zürich. 
Kley R., 2010, Der Ökonom Hans Christoph Binswanger, [in:] Wachstum Geld und Geist: Der Ökonom Hans Christoph Binswanger, Kley R. (ed.), VGS Verlagsgenossenschaft St. Gallen im Herbst, St. Gallen.

Kośmicki E., 1988, Etologiczne i socjobiologične rozwinieccie teorii ewolucji. Studium metodologiczne, PWN, Poznań.

Kośmicki E., 1995, Instytut Gospodarki i Ekologii w Wyżsžej Sžkole w St. Gallen, „Ekonomia i Środowisko”, nr 1, s. 217-225.

Kośmicki E., 1995a, O konieczności rozszerzenia Unii Europejskiej o cele i zadania ekologiczne, „Ekonomia i Środowisko”, nr 1, s. 195-201.

Kośmicki E., 2003, Ekologia czasu jako wyz̨wanie dla wspótçesności „Ekonomia i Środowisko", nr 1, s. 5-24.

Kośmicki E., 2011, Przedmowa do wydania polskiego, [in:] Spirala wzrostu. Pieniqdそ, energia $i$ kereatywność w dynamice procesów rynkowych, Binswanger H.Ch., Zysk i S-ka, Poznań.

Kutschera U., 2010, Tatsache Evolution. Was Darwin nicht wissen konnte, Deutscher Taschenbuch Verlag, München.

Lumsden Ch., Wilson E.O., 1981, Genes, Mind and Culture, Harvard University Press, Cambridge Mass., London.

Meimberg E., 1995, Homo oecologicus, Wissenschaftliche Buchgesellschaft, Darmstadt.

Meyer P., 1981, Evolution und Gewalt. Ansätze zu einer biosoziologischen Synthese, Parey, Berlin - Hamburg.

Meyer P., 1982, Soziologie und Soziologie. Eine Einfürung in die biologischen Voraussetzungen sozialen Handelns, Luchterhand, Darmstadt-Neuwied.

Meyer P., 2010, Menschliche Gesellschaft im Lichte der Zweiten Darwinschen Revolution. Evolutionäre und kulturalistische Deutumgen im Widersctreit, LIT VERLAG Dr. W. Hopf, Berlin - München - Wien - Zürich - London.

Nutzinger H.G., 2010, Hans Christoph Binswanger Ökonomisches Werk, [in:] Wachstum Geld und Geist: Der Ökonom Hans Christoph Binswanger 2010, Kley R. (ed.), VGS Verlagsgenossenschaft St. Gallen im Herbst, St. Gallen.

Poskrobko B., 2013, Paradygmat zrównoważonego rozwoju jako wiodacy kanon w badaniach nonych obszarów, „Ekonomia i Środowisko”, nr 3, s. 5-30.

Ribaux L., 2010, „Antworten kommen oft von anderswo”-Gedanken eines politischen Weggefährten Hans Christoph Binswanger, [in:] Wachstum Geld und Geist: Der Ökonom Hans Christoph Binswanger 2010, Kley R. (ed.), VGS Verlagsgenossenschaft St. Gallen im Herbst, St. Gallen.

Siebenhüner B., 2001, Homo sustinens. Auf Weg zu einen Menschenbild der Nachbaltigkeit, Metropolis, Marburg.

Strzałko J., 1985, Antropogeneza, [w:] Antropologia, Malinowski A., Strzałko J. (red.), PWN, Warszawa-Poznań.

The Evolution of Man's Capacity for Culture, 1959, Spuhler J.N. (ed.), University Press, Detroit.

Verbeek B., 2001, Die Evolution zur Umweltkompetenz - Wann kommt der Homo oecologicus, "Universitas", no. 10.

Voland E., 2000, Grundriss der Soziobiologie, edition 2., Spektrum, Heidelberg-Berlin. 
Wachstum Geld und Geist: Der Ökonom Hans Christoph Binswanger, 2010, Kley R. (ed.), VGS Verlagsgenossenschaft St. Gallen im Herbst, St. Gallen.

Weisman A., 2014, Countdown. Hat die Erde eine Zukunft?, Piper, München-Zürich.

Wickler W., Seibt U., 1977, Das Prinzip Eigennutz, Hoffmann u. Campe, Hamburg.

Wörterbuch zur Verbaltensbiologie der Tiere und des Menschen, 2006, Gattermann R. (ed.), Spektrum, Heidelberg.

Wuketits F.M., 1997, Soziobiologie. Die Macht der Gene und die Evolution sozialen Verhaltens, Spektrum, Heidelberg - Berlin - Oxford.

Wuketits F.M., 1998, Naturkatastrophe Mansch. Evolution obne Fortschritt, Patmos, Düsseldorf.

Zabel H., 1998, Industriesymbiosen im Verbaltenskontet, [in:] Kreislauforientierte Internehmenskooperationen, Strobel H., Schwarz E. (eds), München-Oldenburg. 